\title{
Human Resources Management in Higher Education Institutions in Poland
}

Katarzyna Szelągowska-Rudzka, Ph.D. Gdynia Maritime University

\section{Introduction}

The 21st century is the time of development of a knowledge-based economy in which higher education institutions play one of the key roles. On the one hand, the challenges of civilization, i.e. globalization, the development of technology and the knowledge-based economy, lead to an increase in the importance and development of higher education (BeckKrala, Klimkiewicz 2011, p. 234; Kwiek 2015, pp. 217-219; Dziedziczak-Foltyn 2011, p. 185; Jakubowska, Rosa 2011, p. 64). On the other hand, the appearance of new university models, changes in social attitudes, economic crises, and competition in the higher education market (Witczak, Mitręga 2015, pp. 417-418) force the introduction of system changes in management, financing (Kwiek 2015, pp. 23-35; Leja 2013, pp. 53-64), as well as the personnel function ${ }^{1}$ at universities". "Skilful management of staff competencies will decide in the future on the attractiveness of the

1 Human resources management and personnel function have been accepted as synonyms (Pocztowski 2008, p. 15).

2 The terms university and higher education institution are used interchangeably in the paper. 
institution, both in terms of the place of work and the place to study" (Modele zarzadzania 2011, p. 90). “(...) It is the people with their qualifications (...), skills and commitment, aspirations and work that make up the success of a university". For all the attributes embodied in those people to produce the expected results, the appropriate conditions should be created by implementing the Human Resource Management (HRM) concept. It refers to strategic thinking in the sphere of human resources (Saczyńska-Sokół 2012, p. 141). It consists in developing HRM strategies and instruments resulting from the organization's development strategy and supporting its implementation while ensuring the care of employees (Szaban 2011, p. 15; Wolska, Kizielewicz 2015, p. 145).

Higher education institutions (HEIs) in Poland, named by T. Wawak (2015, p. 3) as "universities at a crossroads", are perceived as organizations without a management system adjusted to the contemporary tasks they should perform ${ }^{3}$ (Kwiek 2015, pp. 262-289; Sułkowski 2016a, Wawak, 2013, p. 40, Markowski 2011, p. 172; Ryńca 2014, p. 32). The critical voices pointing to the significant delays of Polish universities compared to universities in Western European countries are not uncommon (Jajszczyk, Pacholski 2010, pp. 1-2; Wawak 2013, pp. 46-48). There are also claims that the new economy requires a "new higher education institution" (Santarek 2003, p. 227). A university where the mission, vision, strategic goals and an effective plan for their implementation will be defined (Beck-Krala, Klimkiewicz 2011, p. 240, Jajszczyk, Pacholski 2010, p. 2). A university management system based on a well-designed development strategy will effectively deliver on the key missions of the university, i.e. student education, research, and collaboration with stakeholders (Leja 2013, pp. 60, 159) and will enable its development and improvement (Wawak 2013, p. 48).

The amendment of the Law on Higher Education, introduced in 2011, imposed on the organs of higher education institutions - the rector and managers of basic organizational units - the obligation to develop strategies (of universities and units). Previously, such actions, although recommended, were not common. The research conducted in 2011 showed that only $27 \%$ of public HEIs have a strategic document, $39 \%$ have mission and only $7 \%$ - strategic vision ${ }^{4}$. No results were

3 Despite being included in the European Higher Education Area (as part of Bologna Process) and implementation of Lisbon Strategy and "Europe 2020" strategy goals (Dziedziczak-Foltyn 2011, pp. 183-185).

4 Ultimately a rather limited importance of the mentioned documents for the practice of management of state HEIs was found (Markowski 2011, pp. 172- 174). Simultaneously, the conclusions of previous World Bank studies were proven, indicating the insufficient formulation of the vision of the future and strategic planning in Polish universities (Dziedziczak-Foltyn 2011, p. 184). 
provided for actions in the area of HRM (Markowski 2011, p. 173). Universities pay even less attention than they have strategies devoted to the issues of HRM. Yet, without a well-implemented HR function that takes into account the interests of both academic teachers ${ }^{5}$ and other (administration, engineering and technical) employees, it will be impossible to progress in the field of efficient university management and to increase the prestige and competitiveness of Polish higher education institutions internationally (Witczak, Mitręga 2015, p. 415; Gajda, Cichon 2013, p. 143; Ryńca 2014, p. 144).

The success of a university - just like of any organization - depends primarily on the people it employs, on their competence, commitment and motivation to perform the mission, goals and tasks. University employees are its particular asset (the carrier of the human capital needed to build competitive advantage; Gwizdała 2011, pp. 243-245). Their satisfaction with their work influences the results achieved by the university, the level of educational services provided and the quality of scientific research (Ryńca 2014, pp. 11, 143-144; Grobelna, Sidorkiewicz, Tokarz-Kocik 2016, s. 282-284). It is therefore essential to develop HRM tools that will result in employee satisfaction as well as the development of their competence and involvement in the university matters.

The aim of the study is the diagnosis of the human resources management in Polish higher education institutions, the indication of the directions of changes that have recently taken place in HEIs in the field of HRM, and the indication of the areas (sub-processes) functioning properly and those in need of improvement. The aim has been achieved upon the review of source literature. First the article presents the essence and components of HRM in the context of the university management system, theoretical solutions, and applicable law regulations; next their practical implementation is analyzed. Public universities and research and teaching staff are primarily concerned in the analysis due to the availability of publications devoted to the subject.

\section{The Essence of Human Resources Management and its Main Sub-functions in Higher Education Institutions}

M. Armstrong defines human resources management as "a strategic, homogeneous and coherent approach to managing the most valuable assets

5 They are the research and teaching staff, teaching staff, research staff, certified librarians, and MLS reference librarians (Law 2005, Art. 108).

Human Resources Management in Higher Education Institutions in Poland 
of any organization - people, who individually and collectively contribute to the achievement of all goals set by the organization and thereby strengthen its competitive edge" (Armstrong 2000, p. 19). In order for HRM activities to be effective in a higher education institution, they have to stem from its strategy, be integrated with it, so that employees, through everyday work, contribute to the achievement of the mission and goals resulting from it (Saczyńska-Sokół 2012, p. 143; Zając 2007, p. 19; Spodarczyk 2016, pp. 248249).

The universal goal of HRM is to provide value to stakeholders ${ }^{6}$, build a competitive position of the organization by achieving high work efficiency, increase the value of human capital, build employee engagement while taking into account their needs (Pocztowski 2008, p. 34; Zając 2007, p. 14). The creation of appropriate, internally consistent processes and procedures of HRM and the care for a high standard of HRM practices for each group of employees will lead to an increase in their competencies ${ }^{7}$ (Modele zarzadzania 2011, p. 90), their engagement in work for the university benefit (Beck-Krala, Klimkiewicz 2011, p. 242).

The effectiveness of the process of human resources management in a higher education institution, giving it a strategic character, requires linking with the strategy of action through the development of a personnel strateg $y^{8}$. The European Commission - due to the importance of the HRM issues - encourages universities to implement the HRM strategy based on the guidelines of the European Charter for Researchers (Charter) and the Code of Conduct for the Recruitment of Researchers (the Code). These documents include forty principles divided into four groups: ethical and professional aspects, recruitment, working conditions and social security, and training (Report 2015, pp. 19-29). The analysis of the current state and proposing improvement actions in terms of the personnel strategy based on these

6 People, institutions concerned with the university, influencing it, i.e. employees, students, enterprises, local government units, national administration, media, NGOs, trade unions, other universities (Beck-Krala, Klimkiewicz 2011, p. 237).

7 Knowledge, experience, practical abilities, psycho-physical features, skills and predispositions, internal motivation, attitudes and behaviors being components of human capital (Gwizdała 2011, p. 245).

8 Otherwise called HRM strategy - a coherent configuration of activities including setting long-term goals, principles, plans and programs concerning employees, aimed at creating and using human capital as a guarantor of achieving and maintaining a competitive advantage in the future (Pocztowski 2008, p. 53). 
principles, aims to create versatile conditions for scientific development of the academics (https://euraxess.ec.europa.eu/jobs/hrs4r).

Human resources management includes three main HR processes, i.e.: people's entering the organization, their functioning in it, and their leaving (Pocztowski 2008, p. 36). These, in turn, are divided into universal partial processes. Their number and structure are presented differently by different authors ${ }^{9}$. The selection of individual sub-processes and the degree of their development in organizations results from their specificity (i.e. size, structural, organizational, technical, and financial possibilities, the potential of employees) (Zając 2007, p. 20). In the case of universities, the following HR subsystems are distinguished (Modele zarzadzania 2011, p. 91, Law 2005): employment planning, recruitment of employees, establishing and terminating employment relationships, assessment of employees, their development, motivation and remuneration. The abovementioned HRM sub-processes will be presently characterized.

Employment planning should address each of the groups of university employees, both academic and administrative or engineering and technical staff (Modele zarzadzania 2011, p. 91). The recruitment of academic teachers is based on competitions for posts; it should be purposeful ${ }^{10}$, and based on very high standards (Beck-Krala, Klimkiewicz 2011, p. 243). The European Commission recommends in the Charter and the Code the application of clear recruitment standards; open, effective, transparent recruitment procedures adapted to the type of position offered; informing in detail about employment conditions and recruitment results (even the people not accepted for work); taking into account national and international mobility as well as different experiences of candidates (e.g. in the public and private sectors); avoiding any form of discrimination, so as to provide employees (including those with a PhD degree) with the opportunity to develop a research career in a long-term perspective (The European Charter... 2005, p. 4-8).

Establishing an employment relationship with an academic teacher is regulated by art. 118-121 of the amended Law on Higher Education (Law 2005, pp. 111114), which state that it may take place on the basis of nomination (only those with a professor's title) or a contract for a specified or unspecified period (other

9 Due to the limited size of the study, these classifications will not be discussed.

10 I.e. adjusted to the majors and specialties, the number of students, taking into account the minimum academic staff complements and the appropriate employment structure, i.e. the number of senior academic employees, full time employees, employed for a specified period) (Modele zarzadzania 2011, pp. 91-100; 103-105). 
employees). The Law also specifies the rules for termination and expiration of employment (art. 123-127, Law 2005, pp. 115-118).

The assessment of academic teachers, in accordance with the Law (art. 132), covers their didactic, scientific and organizational activities and the observance of copyright and related rights, as well as industrial property rights. These issues are also highlighted by the European Charter for Researchers and the Code of Conduct for the Recruitment of Researchers (The European Charter ... 2005, pp. 1-2, 4, 12-13). The assessment should be run in a strictly arranged time, in accordance with the rules and the procedure specified in the university statute. The evaluation of academic teachers also includes an opinion about their work expressed by students and doctoral students (Law 2005, p. 123).

The development of academic teachers means upgrading their knowledge to properly perform at their current positions and developing additional competencies with regard to promotion, redeployment or organizational change (Modele zarzadzania 2011, p. 112; Beck-Krala, Klimkiewicz 2011, p. 243). The career path of academic teachers is strictly formal (doctoral degree, habilitated doctor, professor title) and its course is determined by the Law (2005, art. 120, pp. 113114) and the statute of the university. The development of research and teaching staff is also made through participation in postgraduate studies, conferences, seminars, symposia, training trips and through national and international grants (Modele zarzadzania 2011, pp. 114-115). As stated in the Charter and the Code, the development of employees should be supported by superiors, scientific supervisors and more experienced employees (The European Charter... 2005, pp. 12, 14-16).

Motivating academic teachers has a material and an intangible dimension. The first one consists of fixed remuneration, governed by specific regulations, and additional remuneration relevant at a given university (such as bonuses rectors' awards), as well as social benefits. The need to provide researchers with fair and attractive financial and social security conditions at every stage of their careers is also emphasized by the Charter and the Code of the European Commission (The European Charter... 2005, p. 10). Intangible incentives relate to the prestige of work at a university, sense of security and stability, autonomy, freedom of action and independence, delegation of power, personal development, participation in conferences, seminars, language trainings, flexible working hours, the possibility of conducting didactic classes on the basis of own research (Modele zarzadzania 2011, pp. 120, 243; Beck-Krala, Klimkiewicz 2011, p. 243). 


\section{HRM Practices in Polish Higher Education Institutions in the Light of Source Literature}

The diagnosis of the practice of the use of HRM in Polish universities will be made on the basis of a review of available publications referring to the results of empirical research.

The most optimistic conclusions from the research carried out on the example of selected universities in 2003 and 2010 are presented by S. Saczyńska-Sokół (2012). The author points out that some progress in the strategic approach to HRM in Polish higher education institutions has been made. This is evidenced by the following premises (2012, pp. 144-148):

1. The importance of a strategic long-term approach to the HR sphere which is increasingly formalized has doubled (from 30\% to 60\%) and is reflected in the mission and strategy of the university, in setting specific HR goals. The number of schools with missions (considered the key to strategic activities) increased in the studied group of cases from about $40 \%$ in 2003 to $87.5 \%$ in 2010 and in $86 \%$ of them references to HR matters are found ${ }^{11}$. The researched activities in the field of HRM primarily focus on research and teaching staff, more rarely do they refer to administration, engineering, technical or service positions.

2. However, HRM in the surveyed entities is still not fully comprehensive, i.e. it does not constitute a human resources management system based on a coherent, total integration of individual components (sub-functions) with one another and the university strategy but involves the implementation of only selected "fragments" of the system (varied in each university).

3. 55\% of surveyed universities (including 30\% public ones) declared having and implementing a personnel strategy, of which $91 \%$ were official documents.

4. $95 \%$ of these schools carry out long-term planning in the area of personnel function. In $55.3 \%$ of them it is formalized, which shows more than a double increase compared to 2003 and indicates the growing importance of this subfunction of HRM.

11 The conclusions from S. Soczyńska-Sokół's research are more optimistic than the conclusions from the research cited in the introduction of the study, which M. Markowski reffered to. The differences result from the specifics of both tests and the selection of the sample (different universities). In general, it should be understood that despite the observable improvement (see Soczyńska-Sokół), the scale of changes in the field of HRM development in universities in Poland is still insufficient (see Markowski), requires further improvement measures of a greater and deeper scope.

Human Resources Management in Higher Education Institutions in Poland 
5. Most commonly the surveyed universities attribute the strategic importance to the recruitment of employees (mainly the increase in employment of research and teaching staff) and their development; they declare a constant growth of their knowledge and skills. The sub-function of employee recruitment is elaborate. Development issues have a more general form (e.g. gaining senior academic employees), they do not present particular ways or tools to achieve the key objectives. They most often refer to the activation of employees in the field of research within the university and in cooperation with other centers.

S. Saczyńska-Sokół also observes that:

1. In practice, the HRM in the surveyed entities is still not fully comprehensive, i.e. it does not constitute a human resources management system based on a coherent, comprehensive linking of individual sub-functions with each other and the university's strategy (despite the fact that $87 \%$ of surveyed universities declare this). It consists in the implementation of only "elements" of the system, selected depending on the university.

2. The researched universities far less commonly attribute strategic character to the aspect of motivating and evaluating employees. The motivating function mainly covers strategic tasks for developing new motivating and pay systems. Less space is devoted to multi-jobbing, which was highlighted in previous studies (2003) and is being debated in relation to the condition and determinants of the development of higher education in Poland (Kwiek 2015, Leja 2013, Sułkowski, 2016a).

Ł. Sułkowski, based on research on the quality culture of Polish higher education institutions (Sułkowki 2016b; Sułkowski 2016a) states that their management system still needs improvement. This concerns both the design and implementation of university strategies as well as the HR strategy and HRM practices. Although the first steps in the strategic approach to human resources management in higher education institutions have been made, "the process was enforced by law (...), a large part of the prepared strategies have the character of formalized and at the same time ostensible, very general and declarative documents" (Sułkowki, 2016b, p. 275). The scope of the undertaken actions remains limited. So far, only 27 Polish higher education institutions (out of 396) have been awarded the prestigious European Commission HR Excellence in Research award, confirming the implementation of human resources management strategies for researchers based on the European Charter for Researchers and the Code of Conduct for the Recruitment of Researchers (https://euraxess.ec.europa.eu/jobs/ hrs4r\#show_ POLAND). 
Ł. Sułkowski states that the employee recruitment and planning process for university staff is based primarily on internal recruitment ("academic inbreeding") and does not promote staff mobility, to which the European Commission pays special attention (The European Charter... 2005, p.22). Despite the competition procedures, the recruitment process is over-formalized, which does not contribute to its transparency or competitiveness. A problem of limited access to contracts for an indefinite period occurs, especially of young employees (Sułkowski, 2016b, p. 270, 275). In general, employment conditions at universities have deteriorated, especially for young employees who do not have a habilitation degree or an academic title of a professor. The professional development (career paths) of academic teachers is not optimistic. There is a lack of new jobs for young, talented employees (Sułkowski 2016a, p. 124) and a reduction in the possibility of promotion to higher positions by $\mathrm{PhD}$ and postdoctoral employees. "The general trend is to reduce funds for employee development" (Sułkowski $2016 \mathrm{~b}$, p. 276). In general, assessment systems, the systems of evaluation of scientific achievements and didactic work gradually created and developed at universities do not yet match with solutions in the business sector with their sophistication. Remuneration of academic teachers, in particular those with high competences, remains lower than salaries in other sectors of the economy. These base salaries depend mainly on the position held and are at a comparable level in public universities. In the majority of universities there is a lack of developed bonus systems related to scientific achievements. A typical solution is still the bonuses and prizes of the Rector (or Dean) for scientific achievements in each year (Sułkowski, 2016b, pp. 270 -277).

Ł. Sułkowski points out that the organizational solutions implemented at universities "have little to offer the employees" (Sułkowski 2016a, p. 123). He indicates the fall of the academic teacher's ethos and prestige, worsening working conditions (especially in non-public schools), decrease in employment stability and security, in job satisfaction, and the attractiveness of working at the university, i.e. through its excessive bureaucracy, reducing to "collecting points", while lacking sufficient funds to conduct research and publish its results in major global magazines (Sułkowski 2016a, pp. 121-124; Sułkowski 2016b, pp. 270-272).

M. Kwiek formulated similar conclusions on the basis of comparative studies carried out in the EU countries. The author states that "the attractiveness of an academic career has been decreasing gradually and inexorably in Poland for two decades (...)" (Kwiek 2015, p. 38), similarly to other European countries. However, Polish universities do not keep pace with these changes and intensifying 
competition. The necessary system changes should lead to the increase in the productivity of academic teachers (the number and quality of publications in reputable periodicals), the internationalization of research, but also to the increase in the external sources of their financing. The author considers these criteria as the main measures of future promotions and career paths (Kwiek 2015, pp. 22-57, 116-119, 301-329).

The authors of the report "Modele zarządzania uczelniami w Polsce" (2010), on the basis of applicable law and organizational practice, state that (Modele zarzadzania 2011, pp. 91-122):

1. Employment planning at universities is linked with the number of students and is not flexible; a certain threat is unfavorable demographic changes falling number of students (less noticeable in universities of recognized reputation), as well as lack of independent employees caused by the retirement of professors and PhDs.

2. Only a small number of full-time positions at universities are occupied as a result of the actual competition of the candidates applying for it. In most cases, the results are foreseeable to all - a particular person enters the competition and wins it ("academic inbreeding") ${ }^{12}$. The authors of the report draw attention to the need to effectively link staff decisions with the scientific (or didactic) achievements of the candidates and the recommendations of the European Charter for Researchers and the Code of Conduct for the Recruitment of Researchers.

3. Observation of the way of assessing academic teachers by universities "implies that it is as labour-consuming as it is inefficient" (Modele zarzadzania 2011, p. 109). Assessment in the sphere of didactics is connected with systematically carried out class observations and evaluations made by students and doctoral students. The assessment of the scientific achievements of employees, especially associate professionals, mainly becomes about collecting points for publications in periodicals. The authors postulate an urgent need to refine the quantitative and qualitative principles of measuring scientific achievements at universities.

4. The path of an academic career is very formalized; its basis is obtaining degrees and academic title on which positions or functions depend. The rule that work and promotion at the university are reserved for objectively the best, is most often not observed. Academic staff also implement individual

12 Sometimes based on non-substantial factors (Wawak 2013, p. 48; Ryńca 2014, p. 37). 
development (trainings, seminars, conferences, postgraduate studies, etc.), however, universities often lack sufficient financial resources for this purpose, as well as for research and publication in recognized journals. As a part of the development and improvement of employees, the authors of the report suggest "conducting appropriate courses (in the field of management, author's note) for the managerial staff, starting from heads of units and departments, and ending up at the rectors" (Modele zarzadzania 2011, p. 114).

5. Positive motivators in higher education institutions are primarily salaries (basic, additional - for a specific period or special ones, and prizes). Their total amount for individual employees may be different due to different sources of income (e.g. participation in projects). Non-financial motivators are, for example, autonomy, freedom of action, development opportunities including education, trainings, conferences, seminars at the expense of the employer, housing, etc. Negative motivation stems from labour law and internal disciplinary proceedings.

Other authors add that the motivational remuneration system based on the results of employees' evaluation, recognized by researchers as very effective in increasing the efficiency and innovativeness of employees, functions in only a few universities in Poland (Markowski 2011, p. 175). The amounts of awards and distinctions received for outstanding achievements, award system and penalties are assessed as relatively low by academic teachers (Ryńca 2014, p. 182). The salaries of university employees, especially the associate professionals, are low (Ryńca 2014, p. 37) and this fact necessitates taking up additional paid work. This is not conducive to scientific development and the preparation of valuable scientific publications (Wawak 2013, p. 48; Sułkowski 2016a, pp. 127128). The systems of granting bonuses dependent on academic achievement are also not sufficiently developed (Sułkowski 2016b, p. 275). The motivating and remuneration systems need to be upgraded, both for the sake of improving the management system and for the quality of scientific work and educational services (Wawak, 2013, pp. 45-47).

The research on satisfaction of the academic teachers of economics of selected universities conducted by R. Ryńca (2014, pp. 172-182) gives rise to some optimism. It turns out that the respondents feel satisfied with their work, its conditions (e.g. safe working conditions, holiday days, university location, access to scientific aids and modern computer equipment), as well as participation in scientific conferences, opportunities for development and formation of one's own career, contacts with co-workers and relations with superiors and the prestige of their university. 


\section{Conclusions and recommendations}

The conducted analysis of the source literature allows us to state that:

1. Human resources management in Polish universities is becoming strategic, there is some progress in this area resulting from the improvement of the management process, implementation of the mission, the vision, the university strategy and the personnel strategy.

2. However, the changes that are taking place are often declarative and formal due to the provisions of the Law, instead of being the actual ones, resulting from strategic planning. They concern fragmentarily individual sub-functions and do not constitute comprehensive activities that make up the HRM system integrated with the development strategy.

3. Not many universities in Poland have implemented the HRM strategy in line with the principles of the European Charter for Researchers and the Code of Conduct for the Recruitment of Researchers and received the award of the European Commission Logo HR Excellence in Research.

4. Individual HRM subsystems at universities meet the guidelines of the subject literature and legal regulations but require improvement.

5. Attention is paid to problems regarding the transparency of the recruitment process, its excessive formalization and a limited number of jobs, especially for young, talented candidates.

6. The development of employees, shaping their career paths and promotions is determined by the gain of academic degrees, the title of professor and the need to meet high requirements for scientific progress most often without providing sufficient financial resources for research and publishing in major periodicals (which is a key issue, both for shaping competitive position of the university, and for researchers).

7. Generally low salaries (mainly for young employees) cause the need for taking up additional work and limit the time for research and scientific development. Motivation is weakened as a result of the increasing lack of sense of security (contracts for specified periods), pressure to earn points without university support and commonly used remuneration and bonus systems related to achievements.

8. HRM in Polish higher schools is determined by the general situation in the higher education system and changes occurring in the European higher education market, to which Polish universities have not yet adapted.

9. It is positive that universities are increasingly appreciating the importance and significance of HRM and are starting to take care of 
personnel issues. The employees themselves (mainly young ones) are also not indifferent to the changes taking place and they adjust to these changes. This is the reason why, in the author's opinion, it would seem beneficial for the improvement of the functioning of the university but also for the improvement of the personnel function, to broaden the involvement of employees in the management process through participatory management style, to appeal to the competencies of academic teachers (knowledge workers), their ideas and suggestions for improvement (Ryńca 2014, pp. 37, 163; Sułkowski 2016a, pp. 126-127; Wawak 2015, pp. 5-6, 10, 23). This would improve the motivation and commitment of employees to the realization of the mission, vision and goals of the university, stimulate their initiative to work, as well as make better use of the human capital of the university.

\section{Summary}

Human resource management is a process whose main goal is to build the competitive position of an organization in the environment by launching and developing the potential of its employees (human capital). For the purposes of HRM to be realized for the benefit of the organization, individual HRM subfunctions must be interrelated, with personnel strategy as well as with the mission and the development strategy. As it has been proven by the above studies, universities in Poland do not yet have a fully formed and efficient management system. The strategies implemented are often declarative in nature and do not have a direct impact on the personnel strategy (which is not commonly present) or the system of related HRM sub-functions. These subfunctions, i.e. job planning, employee recruitment, establishing and terminating employment relationships, employee evaluation, their development, motivation and remuneration, constitute separate areas of operation and do not create an efficient system. In fact, they do not support the development of academic teachers and do not translate into building the position of Polish universities in the European and global system of science and higher education. This fact is also confirmed by a small number of Polish universities holding the Logo HR Excellence in Research. The planning of employment at universities involves rather the ad hoc activities that are not derived from the adopted mission and strategic goals. The recruitment process requires refinement of standards, creation of transparent, effective procedures leading to employing the actually best candidates, who in turn should be provided with attractive working and employment conditions, as well as remuneration, competitive in relation to the 
job market offer. The system of evaluating employees, although it is very extensive and also takes into account the opinions of students and doctoral students, is not directly related to actions leading to their improvement, development of their strengths and elimination of weaknesses. The evaluation system does not promote collaboration and teamwork to achieve university goals and employee goals. The results of the evaluation are not related to the system of motivating, remunerating and shaping the career paths of academic teachers. In principle, all academic teachers have to take care of the development themselves, finding time for it after completing their current didactic tasks. It happens that there is no real systemic, substantive, organizational and financial support from the university. The university expects from academic teachers' scientific productivity above all, which directly translates into its parametric assessment and position in rankings, but human resource management does not create systemic conditions for its formation. In addition, academic teachers (and generally many universities) are struggling with the lack of sufficient financial resources for research and publishing the results in major global magazines. HRM does not support their efforts and everyday work for the implementation of key university missions, i.e. student education, development of science and building relationships with the environment (stakeholders) in a systemic, effective way. It does not create conditions for using the potential of academic teachers as knowledge workers in the process of participatory university management. It does not contribute to stopping the suppression of the prestige of the academic teacher profession, to the improvement of working conditions, employment stability and security, improvement of motivational and remuneration systems, assessment and development of employees. Despite positive changes being observed, the management of human resources in higher education institutions in Poland requires further development and improvement, a link with the mission, vision and strategy for the development of the university, and shaping in the form of a coherent and efficient system.

\section{Abstract}

\section{Human Resources Management in Higher Education Institutions in Poland}

The paper presents the diagnosis of the human resources management in Polish higher education institutions. The analysis of source literature was applied as a research method. The essence and components of HRM in connection with the university management system were discussed, the theoretical solutions, 
including those resulting from the provisions of the Law, and their practical implementations, were given a broad outline. The directions of changes concerning HRM that have recently taken place in HEIs were indicated. In conclusion it was stated that the human resources management in Polish higher education institutions still requires improvement, primarily in the areas of motivation and remuneration, evaluation and development of employees. It requires the improvement of the university management system, a reliable development of its mission, vision and strategy, and on the basis of those - the development of personnel strategy, and HRM processes, procedures and tools. It has been suggested that the inclusion of university employees, particularly the research and teaching staff, in the management process (through the participatory management style), can contribute to both improving the process and developing and improving the personnel function.

Keywords: human resources management, personnel strategy, development strategy, higher education institutions, university management system.

\section{Streszczenie}

Zarządzanie zasobami ludzkimi w szkołach wyższych w Polsce W opracowaniu przeprowadzono diagnozę zarządzania zasobami ludzkimi w polskich szkołach wyższych. Jako metodę badawczą zastosowano analizę literatury przedmiotu. Przedstawiono istotę i elementy składowe ZZL na tle systemu zarządzania uczelnią, przybliżono rozwiązania teoretyczne, $\mathrm{w}$ tym wynikające z przepisów ustawy, oraz ich praktyczne implementacje. Wskazano kierunki zmian jakie $\mathrm{W}$ ostatnim czasie zaszły w uczelniach $\mathrm{w}$ obszarze ZZL. W ramach wniosków i konkluzji stwierdzono, że zarządzanie zasobami ludzkimi w polskich szkołach wyższych wciąż wymaga działań doskonalących. Przede wszystkim w obszarach: motywowania i wynagradzania, oceniania i rozwoju pracowników. Wymaga usprawnienia systemu zarządzania uczelnią, rzetelnego opracowywania jej misji, wizji i strategii, a na ich podstawie strategii personalnej oraz procesów, procedur i narzędzi ZZL. Zasugerowano, że włączenie pracowników uczelni, w szczególności nauczycieli akademickich, 
$\mathrm{W}$ proces zarządzania (przez partycypacyjny styl zarządzania), przyczynić się może zarówno do jego usprawnienia, jak i rozwoju i doskonalenia funkcji personalnej.

\section{Słowa}

kluczowe: zarządzanie zasobami ludzkimi, strategia personalna, strategia rozwoju, szkoły wyższe, system zarzadzania uczelnia.

\section{JEL}

Classification: M12 + I23

\section{References}

1. Armstrong M. (2000), Zarządzanie zasobami ludzkimi, Oficyna Ekonomiczna, Kraków.

2. Beck-Krala E., Klimkiewicz K. (2011), W kierunku kształtowania świadomej polityki społecznej odpowiedzialności uczelni wyższych, "Prace Naukowe Uniwersytetu Ekonomicznego we Wrocławiu", No. 220, pp. 234-247.

3. Dziedziczak-Foltyn A. (2011), Strategie uczelniane - antycypacja, translacja czy pseudokonformiza-cja celów rozwoju szkolnictwa wyższego?, [in:] J. Dworak, J. Jaworski (eds.), Zarządzanie szkoła wyższa. Dylematy $i$ wyzwania, „Prace Naukowe Wyższej Szkoły Bankowej w Gdańsku", vol. 14, pp. 183-202.

4. The European Charter for Researchers and the Code of Conduct for the Recruitment of Researchers "A Human Resources Strategy for Researchers Incorporating the Charter and Code" Annex 1: Example of a Standard Template for the Internal Analysis, http://ec.europa.eu/euraxess/rights (12.01.18 - access date).

5. Gajda J., Cichoń S. (2013), Zarządzanie procesami konsumpcji ustug edukacyjnych w szkole wyższej, „Przegląd Naukowo-Metodyczny. Edukacja dla Bezpieczeństwa", No. 2, pp. 141-168.

6. Grobelna A., Sidorkiewicz M., Tokarz-Kocik A. (2016), Job Satisfaction Among Hotel Employees: Analyzing Selected Antecedents and Job Outcomes. A Case Study from Poland, "ARGUMENTA OECONOMICA", No. 2 (37), pp. 281-310.

7. Gwizdała J. (2011), Kapitat intelektualny w zarzadzaniu szkota wyższa dylematy [in:] J. Dworak, J. Jaworski (eds.), Zarządzanie szkoła wyższą. Dylematy $i$ wyzwania, „Prace Naukowe Wyższej Szkoły Bankowej w Gdańsku", vol. 14, pp. 243-255.

8. Jakubowska A., Rosa A. (2011), Znaczenie szkolnictwa wyższego w gospodarce opartej na wiedzy [in:] J. Dworak, J. Jaworski (eds.), Zarzadzanie szkoła wyższą. Dylematy $i$ wyzwania, „Prace Naukowe Wyższej Szkoły Bankowej w Gdańsku", vol. 14, pp. 63-79. 
9. Jajszczyk A., Pacholski L. (2010), Pomieszane role, "Forum Akademickie", No. 1, styczeń, pp. 1-5.

10. Kwiek M. (2015), Uniwersytet w dobie przemian, PWN, Warszawa.

11. Leja K. (2013), Zarządzanie uczelnią. Koncepcje i wspótczesne wyzwania, Wyd. II uzupełnione, Wolters Kluwer business, Warszawa.

12. Markowski M. (2011), Nowelizacja ustawy Prawo o szkolnictwie wyższym konsekwencje dla zarządzania szkoła wyższa [in:] J. Dworak, J. Jaworski (eds.), Zarządzanie szkota wyższą. Dylematy $i$ wyzwania, „Prace Naukowe Wyższej Szkoły Bankowej w Gdańsku", vol. 14, pp. 169-181.

13. Modele zarządzania uczelniami w Polsce. Raport końcowy (2011), (ed.) M. du Vall, Uniwersytet Jagielloński, Kraków.

14. Pocztowski A. (2008), Zarzadzanie zasobami ludzkimi. Strategie - procesy metody, wyd. II zmienione, PWE, Warszawa.

15. Report of the Expert Group on 'Shaping the Future of the Human Resources Strategy for Researchers - HRS4R' (2015), European Union. https:// cdn1.euraxess.org/sites/default/files/policy_library /experts-reportstrengthened-hrs4r-9-2015_0.pdf (12.01.18 - access date).

16. Ryńca R. (2014), Zastosowanie wybranych metod i narzędzi wocenie działalności szkoły wyższej, Oficyna Wydawnicza Politechniki Wrocławskiej, Wrocław.

17. Santarek K. (2003), Radykalne innowacje, [in:] Przedsiębiorstwo przyszłości - nowe paradygmaty zarzadzania europejskiego, praca zbiorowa, Instytut Organizacji i Zarządzania w Przemyśle „ORGMASZ”, Warszawa.

18. Spodarczyk E. (2016), The Concept of Corporate Social Responsibility in the Micro and Small Enterprise Sector, [in:] F. Pinzaru, C. Bratianu (ed.), Proceedings of the 12th European Conference on Management, Leadership and Governance ECMLG 2016, ACPI, UK, pp. 248-254.

19. Sułkowski Ł. (2016a), Kultura akademicka. Koniec utopii?, PWN Warszawa.

20. Sułkowski Ł. (2016b), Zarzadzanie kapitatem ludzkim w polskich uczelniach, „Prace Naukowe Uniwersytetu Ekonomicznego we Wrocławiu”, No. 429, pp. 269-279.

21. Szaban J. (2011), Zarządzanie zasobami ludzkimi w biznesie $i$ w administracji publicznej, Difin, Warszawa.

22. Ustawy z dnia 27 lipca 2005 r. Prawo o szkolnictwie wyższym (Dz.U. $2005 \mathrm{Nr}$ 164 poz. 1365, Dz. U. z 2012 r. poz. 572, 742, 1544, z 2013 r. poz. 675, 829, 1005, 1588, 1650, z 2014 r. poz. 7). http:/ / isip.sejm gov.pl/DetailsServlet? id=WDU20051641365 (22.10.16 - access date).

23. Wawak T. (2015), Ewolucja koncepcji zarządzania w szkołach wyższych w kierunku wymogów XXI wieku, [in:] J. Dziadkowiec i T. Sikora (eds.), Wybrane aspekty zarządzania jakościa ustug, Wydawnictwo Naukowe PTTŻ, Kraków (https://tadeusz.wawak.pl/content/publikacje-dotyczace-szkolwyzszych; dostęp 12.07.2016).

24. Wawak T. (2013), Wyznaczniki jakości zarzadzania w szkołach wyższych, "Zarządzanie jakością" No. 2 (32), pp. 40-50. 
25. Witczak O., Mitręga M. (2015), Zarządzanie produktywnościa naukowa w kontekście budowania marki, uczelni wyższej, "Zeszyty Naukowe Uniwersytetu Szczecińskiego nr 875. Problemy Zarządzania, Finansów i Marketingu", No. 41, vol. 1, pp. 415-425.

26. Wolska, G., Kizielewicz, J. (2015), Corporate Social Responsibility in Poland Theory and Practice, [in:] I.V. Raguž, Z. Krželj-Čolović (eds.), Proceedings of Scientific Conference on Innovation, Leadership E Entrepreneurship - Challenges of Modern Economy. University of Dubrovnik, Dubrovnic, pp. 143-154.

27. https:// euraxess.ec.europa.eu/jobs/hrs4r (12.09.17 - access date).

28. https://euraxess.ec.europa.eu/jobs/hrs4r\#show_POLAND (12.02.18 access date). 